\title{
A STUDY ON SUPPLY CHAIN ELASTICITY IN 4TH PARTY LOGISTICS COMPANIES
}

\author{
DOI: 10.17261/Pressacademia.2018.990 \\ JMML- V.5-ISS.4-2018(5)-p.311-323
}

Osman Ayan ${ }^{1}$, Melis Gizem Ozturk ${ }^{2}$, Ahmet Murat Koseoglu ${ }^{3}$, Murat Colak ${ }^{4}$

${ }^{1}$ Okan University, Sosyal Bilimler Enstitüsü, Tuzla-Istanbul, Turkey.

ayan tr@hotmail.com, ORCID: 0000-0002-4595-0902

${ }^{2}$ Okan University, IYBF, Tuzla-Istanbul, Turkey.

melis.ozturk@okan.edu.tr, ORCID: 0000-0001-7927-8467

${ }^{3}$ Okan University, IYBF, Tuzla-Istanbul, Turkey.

murat.koseoglu@okan.edu.tr, ORCID: 0000-0002-0656-2798

${ }^{4} \mathrm{DHL}$ LLP, Istanbul, Turkey.

murat.colak@dhl.com, ORCID: 0000-0002-6135-1694

Date Received: August 30, 2018

Date Accepted: December 11, 2018

To cite this document

Ayan, O., Ozturk, M. G., Koseoglu, A. M., Colak, M. (2018). A study on supply chain elasticity in 4th party logistics companies. Journal of Management, Marketing and Logistics (JMML), V.5(4), p.311-323.

Permemant link to this document: http://doi.org/10.17261/Pressacademia.2018.990

Copyright: Published by PressAcademia and limited licenced re-use rights only.

\section{ABSTRACT}

Purpose- In sectors such as logistics where scheduling is Tarafcularly important, the concept of resilience also gains importance. In this study, how resilience measures affect 4'üncü Taraf Lojistik companies examined through DHL case.

Methodology- As a result of case study with a company with special applications for resilience, data were collected.

Findings- Logistics companies aiming to increase resilience can create new and stronger customer base by increasing customer satisfaction with special warning applications for resilience.

Conclusion- Resilience systems are essential for time-driven industries and for 4'üncü Taraf Lojistik companies that are managing supply chain activities for these type of industries. By improving resilience, 4'üncü Taraf Lojistik companies create value for the companies.

Keywords: Logistics, 4'üncü taraf lojistik, supply chain, supply chain resilience.

JEL Codes: L10, L19

\section{4'ÜNCÜ TARAF LOJISTiK IŞLETMELERINDE TEDARIK ZINCIRI ESNEKLiĞi ÜZERINE BíR ÇALIŞMA}

\section{ÖZET}

Amaç- Zamanlamanın özellikle önemli olduğu lojistik gibi sektörlerde esneklik kavramı ayrıca bir önem kazanmaktadır. Bu çalışmada, esnekliğin 4'üncü Taraf Lojistik işletmeleri üzerinde olan etkileri DHL vakası ile incelenmiştir.

Yöntem- Esnekliğe yönelik özel uygulamaları olan bir işletme ile yapılan vaka çalışması sonucunda veriler toplanmıştır.

Bulgular- Esnekliği arttırmayı amaçlayan lojistik işletmeleri, esnekliğe yönelik özel uyarı uygulamaları ile müşteri memnuniyetini arttırarak yeni ve daha güçlü müşteri tabanı oluşturabilmektedir.

Sonuç- Esnekliğe yönelik sistemler, zaman odaklı endüstriler ve bu endüstrilerin tedarik zincirlerini yöneten 4'üncü Taraf Lojistik işletmeleri için bir zorunluluktur. Tedarik zinciri esnekliğini arttırarak 4'üncü Taraf Lojistik işletmeler müşterileri için katma değer yaratmaktadır

Anahtar Kelimeler: Lojistik, 4'üncü taraf lojistik, tedarik zinciri, tedarik zinciri esnekliği.

JEL Kodları: L10, L19 


\section{Giriş}

Insanların ve toplumların birbirleri ile ilişkilerinin ve iletişimin olduğu her yerde ve her zaman diliminde lojistikten bahsetmek mümkündür. Etkileşim nihayetinde toplumların ve kültürlerin ihtiyaçlarına karşılık verebilmektir ve bu karşılığın başladığı tarihin ilk sayfalarından beri lojistiğin varlığından söz edilebilir. Lojistiğin insanın olduğu her yerde olduğunu söylemek yanlış olmayacaktır. İnsan intiyaçları toplum ihtiyaçlarını beraberinde getirirken aynı zamanda lojistiğin de varlığını ortaya çıkarmıştır. Bu varlığın ortaya çıkması ile birlikte lojistiğin zaman içerisinde evrilerek profesyonel bir iş kolu haline gelmesi ve beraberinde bu iş kolunun dünyada gerçekleşen ilerlemeler ve küreselleşmenin ışığında gelişim sağladığı görülmüştür. Lojistik insan ihtiyaçlarını karşılarken aynı zamanda da gelişen teknolojiden yardım almakta ve ilerlemektedir.

Lojistik ile birlikte ele alınması gereken en önemli alanlardan birisi de tedarik zinciri olarak karşımıza çıkmaktadır. Lojistik müşteri ihtiyaçlarını yerine getirme sürecidir. Bu ihtiyaçlar hammaddeden, nihai ürüne, bilgiden hizmete değişiklik gösterebilir. Tedarik zinciri yönetimi ise müşteri ihtiyacına yönelik ürün geliştirmeden müşteri memnuniyeti ve hatta çevre yönetimi ile ilgili süreçlerin tamamını kapsayan stratejik planlama sürecidir (Waters, 2003:51). Tedarik zinciri yönetimi, operasyonel sistemlerden ziyade stratejik karar verme üzerine kurgulanmış stratejik planlama sürecidir. Bu planlama sürecinde kapsam alanının tüm süreçleri dikkatli bir biçimde oluşturulurken diğer bir taraftan da stratejik bir planın dâhilinde gerçekleştirilmektedir.

Lojistik, tipik olarak, tek bir kuruluşun sınırları içinde gerçekleşen faaliyetlere atıfta bulunurken tedarik zinciri, eşzamanlı olarak birlikte çalışan bir sistemin bir ürünü pazara sunma eylemlerini koordine eden işletmelerin ağlarını ifade etmektedir. Lojistik taşımacılık ve tedarik gibi faaliyetlere odaklanmış gözükse de dağıtım, bakım ve envanter yönetimini de kapsamaktadır. Tedarik zinciri yönetimi ise tüm geleneksel lojistiği kabul etmenin yanında pazarlama, yeni ürün geliştirme, finans ve müşteri hizmetleri gibi faaliyetleri de içerisinde barındırmaktadır (Hugos, 2003:4). Tedarik zincirinin pazara dâhil olma sürecinde etkili bir unsur olduğu görülmektedir. Diğer işletmelerin ayrışabilmek için tedarik zinciri yönetiminin koordine bir biçimde çalışan ağlarının olması ve bu ağların her birinin ayrı ayrı eylemlerinin bir bütün eyleme hizmet etmesi beklenmektedir.

Lojistiğin bu kadar gelişmesinden sonra günümüzde kısaca 4'üncü Taraf Lojistik olarak Dördüncü Taraf Lojistik hizmetlerinden bahsedilmektedir. Bu süreçten sonra lojistik hizmetlerinde üretim ve dağıtımdan daha çok müşteri odaklı, teknoloji ile birlikte ilerleyen, geniş bir sorumluluk isteyen, danışmanlığın ön planda tutulduğu bir çalışma ve stratejik planlama beklenmektedir. Bunların sağlanabilmesi adına da tedarik zinciri yönetimi için tedarik zinciri esnekliğinden söz edilmekte ve bu kavram tedarik zincirini oluşturan tüm süreçlere hükmedebilmeyi ifade etmektedir.

\section{LITERATÜR TARAMASI}

Bu kısımda lojistik, tedarik zinciri, tedarik zinciri esnekliği kavramlarına dair bir alan taraması yapılmıştır. Kavramlara ilişkin gelişmeler ve tanımlamalar açıklanmıştır.

\subsection{Lojistik Kavramı ve Gelişimi}

Dünyanın oluşumundan itibaren günümüze dek kendini sürekli yenileyen lojistik geçmişte askeri sahada tam anlamıyla vücut bulmasına rağmen günümüzde hayatımızın her alanında faydalarını gördüğümüz geniş bir tarihi yelpazeye sahiptir. Hayatımızın akışını değiştiren ve hayatımızı kolaylaştıran teknolojik buluşlar ile coğrafi keşifler lojistiğin gelişimine de katkı sağlamıştır (Acar ve Köseoğlu, 2014:7).

Tedarik Zinciri Profesyonelleri Konseyi'ne (CSCMP Council Of Supply Chain Management Professionals) göre lojistik yönetimi; müşterilerin ihtiyaçlarını karşılamak amacıyla malların, hizmetlerin ve bilginin üretim noktasından tüketim noktasına kadar olan çift yönlü akışının ve depolanmasının etkin ve verimli bir şekilde planlandığı, uygulandığı ve kontrol edildiği; tedarik zinciri yönetiminin bir parçasıdır. (Mucuk, 2003:14; Orhan, 2003:8; Acar ve Köseoğlu, 2014:8). Lojistik temelde insan ihtiyaçlarını karşılamak, hayat mücadelesinde üstün gelebilmek açısından tarihte meydana gelen savaşlarda ortaya çıkmış ve kökeni askerlik ile ilişkilendirilmiştir. Savaş olmayan dönemlerde ise yine temelde insan ihtiyaçlarını karşılamak için ekonomik açıdan zenginlik isteği ile devam etmiş ve ticaretin gelişmesi sadece askeri alanda olma kısıdını ortadan kaldırarak daha geniş bir alanda uygulanmaya başlamıştır. Lojistik temelde, hizmetlerin de içerisinde yer aldığı ürünlerin verimli olacak bir biçimde taşınması, depolanması gibi süreçlerde var olan tüm süreçlerin stratejik bir şekilde planlanıp uygulanmasıdır. Ardından söz konusu süreçlerin kontrol edilip ölçülmesiyle birlikte müşterinin tüm istek ve ihtiyaçlarını karşılayacak şekilde tüketimde bulunacak noktaya ulaştırılması ve ulaştırılma sürecinde yer alan tüm adımların koordine edilmesidir.

Lojistik mesleki olarak ilerlerken akademik alanda da çalışmalar başlatılmış ve 1961 yılında lojistik alanının ilk dergisi olarak görülen "Transportation Journal" yayınlanmıştır (Gravier ve Farris, 2008:243). Yine hemen hemen aynı dönemlere denk gelen mesleki örgütlenmenin oluşturulması lojistiğin profesyonel bir meslek olarak görülmesinin önemli adımlarından biri olarak görülmektedir (Acar ve Gürol, 2013:290). Teknolojinin gelişmesi ile birlikte lojistik yönetimi karmaşık bir yapıya dönüşmüş ve 
modern lojistik hizmetleri uygulanmaya başlanmıştır (Büyüközkan'dan akt. Eker, 2006:23) . 2003 yılında Hertz ve Alfredsson lojistik sektörünün gelişimini üç dalgaya ayırmış ve bu üç dalgayı Tablo 1'de belirtildiği şekilde incelemişlerdir (Hertz ve Alfredsson'dan akt. Aydın ve Köseoğlu, 2016: 488):

Tablo 1: Lojistik Sektörü Gelişim Dalgaları ve Özellikleri

\begin{tabular}{l|l}
\hline Gelişim Dalgaları & Özellikleri \\
\hline Birinci dalga & $\begin{array}{l}1980 \text { 'lerde geleneksel nakliye işletmelerin üçüncü Taraf } \\
\text { lojistik işletmelere dönüşümü (bu dönemde lojistik aktiviteler } \\
\text { taşıma ve depolama ağırlıklı algılanmaktadır). }\end{array}$ \\
\hline Ikinci dalga & $\begin{array}{l}1990^{\prime} \text { ların başında sektöre DHL, TNT, FedEx gibi işletmelerin } \\
\text { girişi, }\end{array}$ \\
\hline Üçüncü dalga & $\begin{array}{l}\text { Bugüne uzanan ve finansal ve/veya bilgi teknolojileri } \\
\text { konusunda danışmanlık yapan Anderson Consulting, GE } \\
\text { Capital ve Manugistics gibi işletmelerin sektöre girişi ile } \\
\text { açıklamıştır }\end{array}$ \\
\hline
\end{tabular}

1990'li yılların sonlarında lojistikte yeni bir kavram olan Dördüncü Taraf Lojistik ortaya çıkmıştır. Bu kavramın özünde üçüncü Taraf lojistik anlayışında hâkim olan dış kaynak kullanımı - DKK (outsourcing) kavramından farklı olarak işletme süreçlerinin de dış kaynak yardımıyla organize edilmesi (BPO; Business Process Outsourcing) durumu söz konusu olmuştur (Özdener, 2010: 8889).

Teknolojinin hızla gelişimi ile birlikte adım attığımız her yerde küreselleşmenin izlerini görmekteyiz. Başlangıçta yaşamak için temel ihtiyaçlarımızı karşılama ile başlayan bu adım günümüzde hayatımızın doğal akışının her anına girmiştir. İçtiğimiz su, yediğimiz ekmek ve giydiğimiz kıyafet bunun bir göstergesidir. Ifade edilen ihtiyaçlar doğada yalın haliyle bulunsa bile dünyanın artan nüfusu düşünülerek üretim noktasından tüketim noktası ya da ihtiyaç duyulan noktaya kadar hareketinde lojistik ve lojistik bileşenleri söz konusudur. Farklı iklimlere sahip coğrafyalardaki farklı üretim gayretlerini farklı coğrafyalardaki insanların talebine uygun olarak sunan sistemin halkalarını bir araya getiren ana fonksiyon lojistiktir (Acar ve Köseoğlu, 2014:1). Lojistik, üretildiği noktadan tüketileceği noktaya kadar mevcut süreç içerisinde her türlü ürün, hizmet, bilgi ve para akışının yönetilmesinde yardımcı olan faaliyetlerin tamamıdır (Lambert ve diğ., 1998:2'den akt.Bayraktutan ve Özbilgin, 2015:96).

Lojistiğin çok sayıda ve çok çeşitli tanımı yapılabilmektedir. Bunun da temel sebebi; lojistiğin uygulamalarının oldukça geniş bir alana yayılmış olması ve bu nedenle bu kavrama farklı farklı pencerelerden bakılabilmesidir (Gülenç ve Karagöz, 2008:75). Lojistik; hammaddelerin, ara ürünlerin ve nihai ürünlerin tedarikçilerden işletme içi süreçlere ve ardından da müşterilere hareketi ve depolanması ile alakalı bütün faaliyetleri kapsayan yönetim süreci biçiminde tanımlamıştır (Bowersox, 1978; Akt. Vatansever, 2005:3). Başka bir ifade ile lojistik, düşük maliyet ve yüksek kâr kriterlerini sağlamayı öncelikli tutarak, hammadde, ara ürün ve nihai ürünlerin akışı ve stoklanması gibi faaliyetlerin tedarik zinciri içinde stratejik bir şekilde yönetilmesidir (Christopher, 2011:11).

Lojistik yönetimi hammaddenin işletmenin içine girmesiyle imalat sürecinden geçerek müşteriye gitmesi olarak ifade edilebilen tüm malzeme akışıyla ilgilidir. Lojistiği işletmenin planlama, icra ve kontrol yeteneği olarak tanımlanabilmesine rağmen tedarik zinciri bunların nasıl yönetildiğini ifade etmektedir (Weele, 2014:252-253-254).

\subsection{Tedarik Zinciri Yönetimi}

Lojistik yönetimi, hizmetin, bilginin ve malzemenin çift yönlü akışını optimize etmeyi hedefleyen bütünleyici bir süreçtir. Bu süreç başlı başına işletme ve lojistik faaliyetlerini içerir. Sürecin tamamı planlama süreci ve bilgi tabanlı faaliyetlerden oluşur. Pazardan gelen gereksinimler, üretim gerekliliklerine ve daha sonra bu planlama süreci de malzeme gereksinimlerine dönüştürülür. Lojistik konseptinden uygun fayda sağlayabilmek için de tedarikçiden nihai müşteriye doğru lojistik faaliyetlerin entegrasyon, teknolojik ve bilimsel gelişmelerle geliştirilmesiyle birlikte genişletilmesine ihtiyaç gerekmektedir. İşte bu ihtiyacın sonucu olarak değer üreten farklı süreçler ve faaliyetlerde, yukarı ve aşağı bağlantılarla genişletilmiş ve gelişmiş olan yeni entegre yapı tedarik zinciri yönetimi kavramıdır (Waters, 2003:24; Çancı ve Erdal, 2003:49, Christopher, 2011:13). Geleneksel işletme modelleri, şahsi küçük işletmelerin çıkarlarını koruyarak maksimum kar elde etmenin yanı sıra maliyetlerini en aza indirerek en iyi hizmeti sunma esasına dayanmaktaydı. Günümüz tedarik zinciri yönetimi modeli ise; pazarda mevcut rekabet avantajını kaybetmeden mümkün olan en kısa zamanda minimum maliyetle kazancın maksimize edilmesi esasına dayanmaktadır. Bu rekabet modeli, işletmelerin şahsi olarak işletmelere karşı değil, tedarik zincirine karşı tedarik zinciri olarak rekabet edilmesi gerekliliğini ortaya koymuştur. Tedarik zincirleri, bir ürünü veya hizmeti tasarlamak, yapmak, sunmak ve kullanmak için gereken işletmeleri ve iş faaliyetlerini 
kapsamaktadır. İşletmeler tedarik zincirlerine dayanarak hayatta kalma ve gelişmek için ihtiyaç duydukları şeyleri sağlarlar. Her iş bir ya da daha fazla tedarik zincirine sığar ve her birinde oynayabilecekleri bir role sahiptir.

Tedarik zinciri yönetimini etkileyen faktörler rekabetten müşteri taleplerine, küreselleşmeden çalışanların bilgi ve tecrübelerine, bilgiden iletişime ve hatta bulunduğu coğrafyadan o coğrafyaya hakim olan resmi etkilere kadar çok çeşitli olabilir (Öztürk, 2016:21). Etkilendiği faktörler yanında geniş bir disiplin yelpazesine sahip tedarik zinciri yönetimi Tedarik Zinciri Profesyonelleri Konseyi'nin tanımıyla; tedarik, dönüşüm ve tüm lojistik yönetim faaliyetlerinde yer alan tüm faaliyetlerin planlanmasını ve yönetimini kapsar. Tedarikçiler, aracılar, üçüncü taraf hizmet sağlayıcıları ve müşteriler olabilen kanal ortakları ile koordinasyon ve işbirliğini de içerir. Tedarik zinciri yönetimi, işletmeler içindeki ana iş işlevlerini ve iş süreçlerini tutarlı ve yüksek performanslı bir iş modeline bağlama konusunda sorumluluk taşıyan bir işlevdir. Bunun yanı sıra tedarik zinciri yönetimi lojistik yönetim faaliyetlerinin yanında üretim operasyonlarını da içerir ve pazarlama, satış, ürün tasarımı, finans ve bilgi teknolojileri ile birlikte süreçle faaliyetlerin koordinasyonunu sağlar. İşleyen süreçle birlikte faaliyetlerin değişimin hızı ve piyasaların gelişim belirsizlikleri, işletmelerin katılım gösterdiği tedarik zincirlerinin farkında olmaları ve oynadıkları rolleri anlamalarının önemi günden güne artan ivme göstermektedir. Güçlü tedarik zincirlerine sahip olma ve katılımın önemini de öğrenen işletmeler faaliyet gösterdikleri pazarda önemli bir rekabet avantajına sahiptirler (Hugos, 2003:1). Rekabet avantajını sağlamak ve muhafaza etmek ise tedarik zincirine bağlı her bir fonksiyonun kendi içinde ve sistemin bir bütün olarak entegre bir biçimde hareket edebilmesini gerektirmektedir. Günümüz rekabet koşulları işletmeleri bu değişime zorlamakta ve bu değişimi zorunlu kılmaktadır (Özdemirel, 2004:48). Bir tedarik zinciri, bir ürünün pazara tasarım, üretim ve teslimatında yer alan tüm işletmelerden oluşur. Tedarik zinciri yönetimi, sunulmakta olan pazar için en iyi yanıt verme ve verimlilik karışımını elde etmek amacıyla bir tedarik zincirindeki katılımcılar arasında üretim, envanter, yer ve ulaşımın koordinasyonudur. Tedarik zinciri yönetiminin amacı, mal ve hizmet satışlarını nihai, son kullanım müşterisine ulaştırmak ve aynı zamanda hem envanter hem de işletme giderlerini azaltmaktır (Hugos, 2003:40).

\subsection{4'üncü Taraf Lojistik (4'üncü Taraf Lojistik) İşletmeleri}

İşletmelerin etkileyebildiği ve ilgilenebildiği coğrafya aynı zamanda kendisinin de lojistik sınırıdır. Bu sınır coğrafya küçüldükçe küçülür ve büyüdükçe büyür. Aynı yerde alış verişini ve kendi lojistik faaliyetini sürdüren veya lojistik hizmeti alan üretici, gönderici veya tedarikçi(Aydın, Köseoğlu, 2016:487) ile çoğu küçük işletme Birinci Taraf Lojistik(1PL)'i temsil eder (Özovacı, 2016:411; Hai; Yirong, 2002:17).

ikinci Taraf Lojistik (2PL) İşletmeler; düşük getiri, yüksek seviyede varlık yoğunluğu ile tedarik zincirindeki tek veya az sayıda fonksiyon için mal kapasitesi ve/veya hizmet sağlama yanında birinci Taraf işletmelerden ürün ve hizmet satın alırlar (Aydın, Köseoğlu, 2016:487; Özovacı, 2016:411; Hai; Yirong, 2002:17). İkinci Taraf lojistik (2PL) sağlayıcısı, tedarik zincirinin belirli bir alanında uzmanlaşır, genellikle malları bir noktadan diğerine kendi araçlarıyla taşıma imkân kabiliyetine sahiptir.

Daha yüksek maliyetle daha yüksek getiri elde edebilme gayretiyle artan talep karşısında lojistik fonksiyon ve kapasitesini arttırarak operasyonlarını entegre eden ve lojistik servis sağlayan birçok 2PL işletme Üçüncü Taraf Lojistik (3PL)'e dönüşmüştür (Özovacı, 2016:411; Hai; Yirong, 2002:17). 3PL, profesyonel lojistik hizmetleri sağlamak, bu hizmetleri kendilerinin gerçekleştirme sorumluluğunu ortadan kaldırmak için fiziki varlıklar, işgücü ve sistem teknolojisi ile birlikte yönetim becerilerini sağlar. Varlık sahipliğini içerip içermemesine bakılmaksızın 3PL'ler genellikle nakliye, depolama, dağıtım, danışmanlık, optimizasyon, nakliye yönetimi, maliyet değerlendirmeleri ve sözleşme yönetimi gibi hizmetleri sağlama imkan kabiliyetindedir.

Dördüncü Taraf Lojistik(4'üncü Taraf Lojistik), tedarik zinciri boyunca ağ tasarımı, günlük operasyon kontrolü, sözleşme müzakereleri ve 3PL sağlayıcılarının performans yönetimi için müşteri adına çalışan ancak çalışmasını kendi kuruluşunun kaynak, yetenek ve teknolojisini bir araya getirerek uygulayan bir tedarik zinciri entegrasyonunu yönetmek ve tanımlamak için Accenture Ltd danışmanlık işletmei tarafından 1996 yılında önerilen bir kavramdır (Waters, 2003:226; Özovacı, 2016:411). Dördüncü Taraf lojistiği (4'üncü Taraf Lojistik), üçüncü taraf lojistik (3PL) sağlayıcılarıyla aynı rolleri üstlenmenin yanında, müşterinin de stratejik hedeflerine ulaşmasına yardımcı olmak maksadıyla daha geniş sorumluluk ve hesap verebilirliğe sahip önde gelen danışmanlık işletmelerinin ve teknoloji sağlayıcılarının yetkinliklerini kapsamlı olarak entegre eden bir tedarik zinciri çözümü olarak gelişmiştir. (Özovacı, 2016:411). 4'üncü Taraf Lojistik'nin rolü organizasyonun dışında olmanın yanında lojistik verimliliği sağlamak maksadıyla diğer üçüncü tarafların da yeteneklerini bir araya getirme ve entegre etme görevine sahiptir (Bumstead ve Cannons, 2002'den akt. Waters, 2003:341). Bunu da sürekli iyileştirme, maliyet azaltma, yalın lojistik süreçleri ve optimize lojistik ağları ile gerçekleştirir. İşletmeler öz niteliklerini işletme bünyesinde tutarak onlar üzerinden yoğunlaşmak ve yan faaliyetlerini ise dışarıdan sağlayarak maliyet, rekabet, hız ve esneklik avantajı sağlayabilmek maksadıyla dış kaynak kullanımını tercih ederler. Dış kaynak kullanımı veya hizmetlerin dışarıdan sağlanması, küreselleşmenin ve gelişen teknolojinin oluşturduğu yoğun rekabetli ortamda, işletmelerin hız, esneklik ve maliyet avantajları sağlayabilmeleri için geliştirilmiş bir kavramdır (Mersin, 2003'den aktaran Özdemirel,2004:2). Dış kaynak kullanımı ile ana faaliyetler sınıflandırılarak işletme bünyesinde tutulur, yan faaliyetler ise 
dışarıdan sağlanarak maliyet, esneklik, hız ve rekabet avantajı sağlanır (Özdemirel,2004:3).4'üncü Taraf Lojistik'nin temel işlevi burada ortaya çıkar, işletmeye entegrasyon sağlar ve bu sayede müşterisinin sürekli yenilik ve tedarik zinciri performansında iyileşme için gerekli olan vizyona sahip olmasını sağlar. Tedarik zinciri yönetiminde tam bir entegrasyon hedefleyen bu hizmet müşteri ve sağlayıcı arasında samimi bir ortaklık olmasını da sağlamaktadır. Bu stratejik rol; rekabet, müşteri memnuniyeti, değişen durumlara adaptasyon ve tehlike arz eden durumlarda esneklik için hızla gelişen dünyada yer bulmaya başlamıştır. İlk kullanımda 4'üncü Taraf Lojistik terimi, hiçbir zaman lider yüklenicinin veya belirli bir işletmei yöneten üçüncü şahıs operatörünün çalışması için tasarlanmamıştır (Waters, 2003:341). 4'üncü Taraf Lojistik sağlayıcının gerçekten gerekli olup olmadığına yönelik Wisconsin-Stout Üniversitesi'nden Nezar Al-Mugren tarafından yapılan araştırmada; teknoloji eksikliği, karmaşıklık artışı, küresel iş operasyon artışı gibi ana sebepler ortaya konmuştur (What is Logistics and Supply Chain Management?). Bunun yanında operasyonel maliyetlerin kontrolü, işletmeninin değer artırıcı faaliyetlere odaklanması, uluslararası standartlara ulaşılması, kaynak tasarrufu, lojistik imkanlarının yetersizliği karşısında yeni fırsatlar, e-ticaretin küresel gelişimi, risk paylaşımı, proje yönetimi, esneklik, envanter planlama gibi faktörler de 4'üncü Taraf Lojistik işletmelerin işletmeler için 4'üncü Taraf Lojistik ihtiyaç sebepleridir (DHL - Fourth Party Logistics). Tablo 2'de lojistik işletmelerinin özellikleri ve türleri incelenmiştir.

Tablo 2: Lojistik İşletmeleri ve Özellikleri

\begin{tabular}{l|l}
\hline Lojistik İşletmeleri & Özellikleri \\
\hline Birinci Taraf Lojistik(1PL) & $\begin{array}{l}\text { Aynı yerde alış verişini ve kendi lojistik faaliyetini sürdüren } \\
\text { veya lojistik hizmeti alan üretici, gönderici veya tedarikçi }\end{array}$ \\
\hline Ikinci Taraf Lojistik (2PL) & $\begin{array}{l}\text { Tedarik zincirinin belirli bir alanında uzmanlaşır, genellikle } \\
\text { malları bir noktadan diğerine kendi araçlarıyla taşıma imkân } \\
\text { kabiliyetine sahiptir }\end{array}$ \\
\hline Üçüncü Taraf Lojistik (3PL) & $\begin{array}{l}\text { Nakliye, depolama, dağıtım, danışmanlık, optimizasyon, } \\
\text { nakliye yönetimi, maliyet değerlendirmeleri ve sözleşme } \\
\text { yönetimi gibi hizmetleri sağlama imkan kabiliyetindedir }\end{array}$ \\
\hline Dördüncü Taraf Lojistik(4'üncü Taraf Lojistik) & $\begin{array}{l}\text { (3PL) sağlayıcılarıyla aynı rolleri üstlenmenin yanında, } \\
\text { müşterinin de stratejik hedeflerine ulaşmasına yardımcı } \\
\text { olmak maksadıyla daha geniş sorumluluk ve hesap } \\
\text { verebilirliğe sahip önde gelen danışmanlık işletmelerinin ve } \\
\text { teknoloji sağlayıcılarının yetkinliklerini kapsamlı olarak } \\
\text { entegre eden bir tedarik zinciri çözümü }\end{array}$ \\
\hline
\end{tabular}

Not: Özdemirel (2004)'den uyarlanmıştır.

\subsection{Tedarik Zinciri Esnekliği ve Önemi}

Günümüz dünyası ile gelecek belirsizlik bilinmezliklerle doludur. Hızla değişen tüketici alışkanlıkları talepte de dalgalanma ve değişikliklere yol açmaktadır. Belirsizlik ve bilinmezlikleri sadece tüketici ile sınırlamak yanlış olur. Ekonomik, teknolojik, coğrafi, siyasi, kanuni ve insan kaynaklı(grev/lokavt, terör eylemleri vb.) birçok değişiklik olması muhtemel ve muteberdir. Bu değişikliklerin hızı, etkisi ve süresi gibi birçok değişken söz konusudur. Lojistik işletmelerin hüküm sürdüğü, etkilediği ve etkilendiği coğrafyanın büyümesi ve küçülmesi ile işletmenin lojistik yetkinlik büyüklüğünün doğru orantılı olması yanında karşı karşıya kalacağı risk, tehdit ve şokların etkisi de büyüyecek ya da küçülecektir. Bunların tehdit olarak algılanması ya da önlem alınması ise işletmein mevcudiyetinin korunma isteğiyle ilişkilendirilebilir. Sonuç olarak, işletmelerin tedarik zincirleri bu tehditlere karşı hassastır ve sonucunda şokun etki derecesi işletmenin iş sürekliliğinden işletmenin mevcudiyet riskine kadar etki edebilir. Geçmişte, işletmelerin tedarik zinciri tasarımının maksadı maliyetin en aza indirgenmesi ya da hizmet iyileştirme idi, günümüzde ise artık esneklik üzerinde durulması gerekmektedir (Christopher, 2011:24; Falasca, Zobel ve Cook, 2008:597).

Geniş coğrafyalarda küreselleşme, teknolojik gelişmeler ve ticari değişikliklerin sonucu olarak tedarik zinciri ağlarının karmaşıklığı gitgide artmakta ve bu da çeşitli riskler doğurmaktadır. Tedarik zincirinin ağ zayıflığı, pazar ve tesisler arası uzaklık, savaş, salgın hastalık, deprem vb. riskler geçmişte ufak yerel aksamalara neden olabilecekken günümüzde büyüyen endüstrileşme ve büyüyen ekonomiler karşısında işletmelerin karşısında eskisinden daha büyük şekilde problem olarak ortaya çıkacaktır. Buna karşın tedarik zinciri yöneticileri de rekabet avantajı yaratma ve sürdürebilme yeteneğine sahip, tamamen entegre, etkili ve yetkin tedarik zinciri oluşturmaya çalışmaktadırlar. Pazar ve piyasa taleplerini takip ve yönetme, maliyeti değişen durumlara uyumlaşarak verimliliği dengeleme ideallerini elde etmeye çalışmaktadırlar. Tedarik zincirinin misyonu, hizmet etmek ve zorluklarda, bağımlıları yıkıcı olayların sonuçlarından korumaktır (Berle ve diğ, 2011a'dan akt. Berle ve diğ. 2011:254). 
İşletmelerin geçmişte maruz kalınan ve gerçekleşmesi imkan dahilinde olan olumsuz etkilere önlem alması risk yönetimiyle ilgili iken daha önce maruz kalınmayan ve gerçekleşmesi değerlendirildiği günün şartlarına göre imkan dahilinde görülmeyen olumsuz etkilere önlem alması ise esneklik ile ilgilidir. İşletmeler tarihi verileri kullanarak karşılaşmaları muhtemel engellere, olumsuz olay, tehlike ve risklere karşı önlem alırlar. Bu veriler belirlidir. İncelendiğinde esneklik risk yönetimi ile ilgilidir ancak aynı zamanda, işletmelerin zararlarını en aza indirgeme yeteneği üzerinde odaklandığı ve tedarik zinciri ağının eski haline geri dönmesine olanak sağlaması sebebiyle geleneksel risk yönetim yaklaşımlarından farklıdır (Pettit ve diğerleri 2010; Ponomarov ve Holcomb 2009.dan akt. Ponomarov,2012:6). Benzer şekilde esneklik kavramını risk yönetimi çatısı altında düşünenler de mevcuttur (Zsidisin and Wagner, 2010'dan akt. Remigio,2012:39). Risk yönetimi için işletmeler tarihi verileri kullanarak karar alırlar.

İşletmeler pazarda rekabet avantajı sağlamak ve bunu sürdürülebilir kılarak varlıklarının değerini sürekli maksimumda tutmak isterler. Pazardaki talep karşısında arz ettikleri varlıklarının sürekliliğini de istikrarlı kılmak mecburiyetindedirler. İşletmeler işletme açısından karşılaşabilecekleri iç ve dış tehditlere karşı önlem almalıdır. Gelecek belirsiz tehdit ve tehlikelerle doludur. Geleceğin belirsiz tehditleri karşısında şoka uğrayan bir işletmenin eski normal haline dönebilmesi istikrarını sağlaması ve sürdürülebilir kılması için zorunluluktur. Tedarik zinciri sistemlerinde amaç, rahatsızlıkların olumsuz etkilerini önlemek ve en aza indirgemektir. Problemin ortaya çıkışıla oluşan rahatsızlık durumundan sonra mevcut durumdan kaçınma yeteneği, tedarik zincirinin başarısı için hayati öneme sahiptir (Remigio, 2012:41). Çalkantılı bir değişim karşısında badireyi atlatma, uyarlama ve büyüme kabiliyeti işletmeler için üzerinde yoğunlaşmaları gereken önemli bir sorundur (Pettit, Croxton, Fiksel, 2013:46). Tedarik zincirindeki herhangi bir karışıklığın tüm tedarik zincirinin kısa vadeli finansal performansı üzerinde ve aynı zamanda aşağı yönlü işletme ile son müşterilerin memnuniyet oranı üzerinde de önemli etkiye sahip olduğu düşünülmektedir (Ji ve Zhu, 2008'den akt. Remigio,2012:38).

Esneklik; karşısında tesis, ürün, kaynak, müşteri, pazar vb. üzerinde olumsuz ve köklü değişiklik yapabilecek etkiye sahip beklenmeyen ve kontrol edilemeyen belirsiz süreli şok, problem, tehdit, değişim ve belirsizlik karşısında etkilenen işletmenin etki öncesi durumuna dönebilme kabiliyetidir. İşletmeler bu tehlikeli durumu atlatabilmek ve tehlikeden kurtulabilmek maksadıyla esneklik kabiliyetlerini artırmalıdır. Mevcut kurulu bir sistem üzerinde meydana gelen şok durumunun atlatılabilmesi için sönümleme, adapte olabilme ve dönüşüm kapasitesinin artırılması gerekmektedir (OECD,2014: 7). İşletme sönümleme kapasitesini risk yönetimi ile sağlar. İşletmenin temel yapı ve fonksiyonlarını koruma ve geri kazanmak için önceden belirlenmiş teknik ve taktikleri kullanır. Olumsuz etkileri azaltır ve şokun derecesine bağlı olarak önleyebilir. Şok neyi etkiliyorsa ilgisini orada yoğunlaştııı. Tesislerle ilgili problem yaşanmasına karşın stoku artırma gibi önlemler alabilir. Yalnız bu durum tek başına fazla stok oluşturacağı için önlemden ziyade işletme için yük oluşturabilir. Adapte olabilme ise gelecekteki olası problemlere önlem alma ve fırsatları değerlendirebilmek için, nitelik kaybı olmadan işlev ve yapısal değişiklikle ilgilidir. İşletme dış kaynaktan temin ettiği kaynaklarını tedarikçisinin iflas etmesi ya da rakibiyle anlaşması durumuna karşın tedarikçisinin öz niteliklerini kendi işletmesinin içine dâhil edebilir. Yalnız böyle bir durumda işletme yönetiminin üzerine aşırı yük binmesi haricinde öz niteliklerini de kaybetme riskiyle karşı karşıya kalabilir. Dönüşüm kabiliyeti ise temelde yeni bir sistem kurabilme yeteneğidir. Yeni teknolojik değişiklikler karşısında sistemi hızla değiştirme kabiliyeti olarak karşımıza çıkabilir.

Planlanan mevcut süreç öngörüldüğü gibi gitmez ve yıkıcı bir etkiyle karşılaşırsa bu durumda işletme ikincil planını uygulamaya koymalı ve öngörülen diğer sürece göre hareket etmelidir. İkinci bir planı yoksa ya da yaptığı diğer planlar sekteye uğruyorsa dış destek almalıdır. Farklı bir deyişle buna hizmet alımı da diyebiliriz.

Tedarik zinciri esnekliğinin temel bileşenleri Pettit vs. (2013) tarafından iki aşamada incelenmiştir. Bu aşamalar zayıfıklar ve yeterlilikler olarak sınıflandırılmıştır. Zayıflıklar olarak kasten tehditler, bağlantı, dış baskılar, kaynak limitleri, duyarlılık, tedarikçi/müşteri bozulması, türbülans, yeterlilikler olarak ise adapte olabilirlik, beklenti, kapasite, işbirliği, dağılım, verim, finansal güç, siparişlerin eksiksiz yerine getirilebilmesi, kaynak esnekliği, Pazar konumu, organizasyon, kurtarma, görünürlük ve güvenlik olarak belirlenmiştir. Tablo 3'te Tedarik Zinciri esnekliğinin temel bileşenleri SWOT analizi kapsamında incelenerek sınıflandırılmıştır. 
Tablo 3: Tedarik Zinciri Esnekliği ve Bileşenleri

\begin{tabular}{|c|c|c|}
\hline Zayıflık/Güvenlik Açığı Faktörü & İç Alt Faktör (Zayıf Yönler) & Dış Alt Faktör (Tehditler) \\
\hline Kasten Tehditler & Casusluk, İş Uyuşmazlıkları, Hırsızıık, Sabotaj & $\begin{array}{l}\text { Terörizm, Özel ilgi grupları, Ürün } \\
\text { sorumluluğu }\end{array}$ \\
\hline Bağlantı & & $\begin{array}{l}\text { Ağ ölçeği, Bilgiye güvenme, Dış kaynak } \\
\text { temini, İthalat ve İhracat kanalları, Özel } \\
\text { kaynaklara güvenme }\end{array}$ \\
\hline Dış Baskılar & Rekabetçi yenilik, Kurumsal sorumluluk & $\begin{array}{l}\text { Sosyal / Kültürel değişim, Siyasi / Düzenleyici } \\
\text { değişim, Fiyat baskıları, Çevresel değişim }\end{array}$ \\
\hline Kaynak Limitleri & $\begin{array}{l}\text { Üretim ve Dağıtım kapasitesi, İnsan } \\
\text { kaynakları }\end{array}$ & Tedarikçi, Hammadde ve Kamu Hizmetleri \\
\hline Duyarlılık & $\begin{array}{l}\text { Paydaşlara görünürlük, Markanın sembolik } \\
\text { profili, Kapasite yoğunlaşması }\end{array}$ & $\begin{array}{l}\text { Karmaşıklık, Ürün saflığı, Sınırlı malzemeler, } \\
\text { Kırılabilirlik, Ekipmanların güvenilirliği, } \\
\text { Güvenlik tehlikeleri }\end{array}$ \\
\hline Tedarikçi / Müşteri Bozulması & & Tedarikçi güvenilirliği, Müşteri aksamaları \\
\hline Türbülans & Teknoloji hataları & $\begin{array}{l}\text { Doğal afetler, Jeopolitik aksamalar, talebin } \\
\text { öngörülemezliği, Para birimleri ve } \\
\text { fiyatlardaki dalgalanmalar, Pandemik }\end{array}$ \\
\hline Yeterliliklere ait Faktörler & İç Alt Faktör (Zayıf Yönler) & Dış Alt Faktör (Tehditler) \\
\hline Adapte Olabilirlik & $\begin{array}{l}\text { İhtiyaçların hızlıca yeniden yönlendirilmesi, } \\
\text { Kurşun zaman azaltımı, Stratejik oyun ve } \\
\text { simülasyon, Alternatif teknoloji geliştirme }\end{array}$ & $\begin{array}{l}\text { Kesintilerden avantaj yakalama, } \\
\text { deneyimden öğrenme }\end{array}$ \\
\hline Beklenti & Risk yönetimi, iş & $\begin{array}{l}\text { Erken uyarı sinyallerinin izlenmesi, Öngörü, } \\
\text { Sapma ve neredeyse yanlış analiz }\end{array}$ \\
\hline Kapasite & $\begin{array}{l}\text { Rezerv kapasitesi, Yedeklilik, Yedek enerji } \\
\text { kaynakları ve iletişim }\end{array}$ & \\
\hline İşbirliği & $\begin{array}{l}\text { Müşteri yönetimi, İletişim, Siparişlerin } \\
\text { ertelenmesi, Ürün yaşam döngüsü yönetimi }\end{array}$ & İşbirlikçi tahmin, Ortaklarla risk paylaşımı \\
\hline Dağılım & $\begin{array}{l}\text { Dağıtılmış karar verme, Dağıtılmış kapasite } \\
\text { ve varlıklar }\end{array}$ & $\begin{array}{l}\text { Kilit kaynakların ademi merkezileşmesi, } \\
\text { Lokasyona özgü yetkilendirme, Pazarların } \\
\text { yayılması }\end{array}$ \\
\hline Verim & $\begin{array}{l}\text { Atık eleme, İşgücü verimliliği, Varlık } \\
\text { kullanımı, Ürün değişkenliği azaltma, Arıza } \\
\text { önleme }\end{array}$ & \\
\hline Finansal güç & $\begin{array}{l}\text { Sigorta, Finansal rezervler ve likidite, Fiyat } \\
\text { marjı }\end{array}$ & Portföy çeşitlendirme \\
\hline $\begin{array}{l}\text { Sipariş Yerine Getirilmesinde } \\
\text { Esneklik }\end{array}$ & $\begin{array}{l}\text { Geciken taahhüt / Üretim erteleme, Stok } \\
\text { yönetimi, Gereksinimlerin yeniden } \\
\text { yönlendirilmesi }\end{array}$ & $\begin{array}{l}\text { Alternatif dağıtım kanalları, Risk havuzu } \\
\text { oluşturma / paylaşma, Çoklu kaynak } \\
\text { sağlama }\end{array}$ \\
\hline Kaynak sağlamada esneklik & Parça ortaklığı, Modüler ürün tasarımı & $\begin{array}{l}\text { Çoklu kullanımlar, Tedarikçi sözleşmesi } \\
\text { esnekliği, Çoklu kaynaklar }\end{array}$ \\
\hline Pazar konumu & $\begin{array}{l}\text { Ürün farklılaştırması, Müşteri sadakati / } \\
\text { pazar payı, Pazar payı, Marka değeri, } \\
\text { Müşteri iliş̧ileri, Müşteri iletişimi }\end{array}$ & \\
\hline
\end{tabular}




\begin{tabular}{l|l|l}
\hline Organizasyon & $\begin{array}{l}\text { Sorumluluk, Yaratıcı problem çözme, Çapraz } \\
\text { eğitim, Yedek liderlik / yetkilendirme, } \\
\text { Öğrenme / kıyaslama, Bakım kültürü }\end{array}$ & \\
\hline Kurtarma & $\begin{array}{l}\text { Kriz yönetimi, Kaynak seferberliği, İletişim } \\
\text { stratejisi }\end{array}$ & Sonuç azaltma \\
\hline Güvenlik & $\begin{array}{l}\text { Katmanlı savunmalar, Erişim kısıtlamaları, } \\
\text { Çalışan katılımı, Siber güvenlik, Personel } \\
\text { güvenliği }\end{array}$ & Hükümetler ile işbirliği \\
\hline Görünürlük & & $\begin{array}{l}\text { İ̧̧ zekası toplama, Bilgi teknolojisi, Ürün, } \\
\text { ekipman ve insan görünürlüğü, Bilgi değişimi }\end{array}$ \\
\hline
\end{tabular}

Not: Pettit vd., 2013

\section{YÖNTEM VE BULGULAR}

Çalışma vaka araştırması şeklinde yapılmıştır. Bu kapsamda tedarik zincirli esnekliğine yönelik kendilerine özel uygulamaları olan bir işletme ile yapılan yarı yapılandırıımış görüşme ile veriler toplanmıştır. Çalışma kapsamında örnek olay incelemesi olarak uluslar arası alanda faaliyet gösteren bir işletme incelenmiştir. İşletmenin Lojistik Hizmet Sağlayıcı Bölüm Direktörü ile nitel araştırma yöntemlerinden yüz yüze görüşme tekniği ile görüşme gerçekleştirilmiştir. Görüşme sırasında tedarik zincirinde esneklik kavramı ile ilgili 11 tane soru sorulmuştur. Bu sorular yapılan literatür taraması, sektör temsilcileri ve konu ile ilgili akademik personel ile yapılan görüşmeler neticesinde belirlenmiştir. Yapılan görüşme sırasında belirlenen sorulara verilen cevaplar incelenerek bulgular ortaya çıkarılmıştır.

Araştırmanın temel amacı tedarik zinciri esnekliği kavramının Dördüncü Taraf Lojistik işletmeleri üzerindeki etkilerini belirlemektir. Bu kapsamda araştırma sorusu olarak: "Tedarik Zincirinde Esneklik kavramı ve kavramın Dördüncü Taraf Lojistik işletmeları üzerindeki etkileri" belirlenmiştir.

Tedarik zincirinde esneklik kavramı; "Proaktivite, sorunlarla daha önceden yapılan planlar dâhilinde başa çıkabilmek, maliyetten kaçınma, çeviklik ve sağlamlık gibi faktörlerin bir tedarik zincirinde bulunması tedarik zincirinde esneklik kavramını ortaya çıkartır". Şeklinde algılamaktadır. Bu doğrultuda; Tedarik zinciri esnekliğinin öncelikli olarak öngörülen veya öngörülemeyecek sorunlar için başa çıkabilme yeterliliği olarak karşımıza çıktığı görülmektedir. İşletmeler için esneklik maliyetleri yönetebilme, çıkabilecek sorunlar karşısında güçlü bir direnç gösterebilme özellikleri bulunmaktadır. Bu özellikler sürekli dalgalanma halinde bulunan günümüz dünyasında sorunlar ile başa çıkabilmek için bir yetenek olarak oluşturulmalıdır.

Tedarik zinciri esnekliğine ihtiyacın duyulma sebepleri farklılık göstermekle beraber; “Tedarik zincirleri özellikle bölgesel aktivite gösteren tedarik zincirleri kırılgan yapılardır. Bu kırılgan yapılarla başa çıkmak için işletmeler envanter tutmayı tercih ederler, bu da maliyet anlamına gelmektedir. Envanteri azaltmak da tedarik zincirinin kırılganlığını arttırabilir. Yüksek envanter, yüksek maliyet demektir. Durumu tersine çevirmek, az envanter ile de kırılganlıkla başa çıkabilen tedarik zincirleri geliştirmek için esneklik önemli bir kavramdır. Rekabetçiliği arttırabilmek ve bir adım öne geçebilmek için esneklik önemli bir araç olarak belirtilebilir. Esneklik kavramı özellikle kırılgan yapı gösteren tedarik zincirleri açısından maliyetleri en aza düşürmek ve bununla birlikte daha az envanter kullanmak açısından önem taşımaktadır. Normal şartlarda envanter kullanımın azaltılması kırılganlığı arttırabilecek bir durumken, esneklik kullanmak ile bu kırılgan yapı en aza indirilebilmektedir. Yine bu noktada rekabet durumlarında esnekliğin diğerlerinden farklılaşma açısından önem taşıdığı görülmektedir.

Geliştirilen program; yurtdışında LLP (Lead Logistics Provider) Türkiye'nin verdiği geribildirimler ile geliştirilen bir sistem olarak karşımıza çıkmaktadır. Bölgesel ve küresel tedarik zincirlerinde dış kaynaklı etkenler kırılganlığı etkilemektedir. Kontrol dışı olan bu durumların kontrol altına alınması için program geliştirilmiştir. LLP’nin amacı tedarik zincirini yönettiği işletmelerin gereksiz maliyetlerini azaltmaktır bu yüzden işletme için ayrı bir programa ihtiyaç duyulmuştur. İşletme açısından bakıldığında, müşterilerin isteği, işletmelerin LLP'den öngörülü olma beklentisi gibi faktörler de programın geliştirilmesinde etkin faktörlerden olmakla beraber bu sistemden önce özellikle sorunlu bölgelerden olan Ortadoğu - Afrika limanlarındaki aktarma limanlarını arayarak günlük olarak doluluk bilgilerini öğrenip ona göre tahminler yürüterek aksiyon alınmakta, eğer doluluk oranı düşükse daha kısa zaman yüksekse daha uzun zaman belirlenmektedir. Fakat geliştirilen program ile limanların hangi tarihlerde yoğun olacağını önceden kestirerek alternatif yollar geliştirilebilmektedir. Program bir sonraki adımda izleme sistemine entegre edilerek hala programsız olarak yapılan aralarındaki ilişki de otomatikleştirilecek, yüklenecek yüklerle ilgili program önceden uyarı verebilecek hale getirilecektir. Tedarik zincirinde esneklik ihtiyacı her alanda olduğu gibi bu alanda da ortada var olan problemlerden yola çıkılarak belirlenmiştir. Daha kısa süre içerisinde daha fazla verim almayı sağlayan ve amaçlayan esnekliğin 
ortaya çıkmasında önemli bir etken olarak geribildirimleri görmekteyiz. Bir alanda ortaya çıkan yenilikler aslında o alanda hissedilen eksiklik ve intiyacı gidermek amaçlı olmaktadır. Esneklik de aynı bu şekilde ortaya çıkmış ve program tüm yapıyı çevreleyen bir şekilde geliştirilmiştir. Önceden belirlenebilen ve öngörülebilen problemler ile programla baş edilebilmekte ve daha çok verim alınabilmektedir.

Tedarik zinciri esnekliğini gerçekleştirebilmek için birtakım faktörleri göz önünde bulundurmak gerekmektedir. Tedarik zincirini etkileyebilecek bütün dış faktörleri göz önünde bulundurulmaya çalışımıştır. Örnek olarak, değişen ekonomik ve siyasi yapı göz önünde bulundurularak sayısı artan grevler verilebilmektedir. 18.12.2017 tarihinde Madrid Havaalanında olan grevi sistem önceden uyardığı için uçak yükleri oradan gönderilmemiş. Maliyeti zaten yüksek olan hava yükleri için özellikle önem taşımaktadır. Program geliştirilirken hava durumu uyarıları, büyük trafik kazaları, gümrük yoğunlukları gibi dış faktörlerin göz önünde bulundurulmasına dikkat edilmiştir. Tedarik zinciri açısından dış faktörler önem taşımaktadır. Bu faktörler politik, ekonomik, sosyal ve teknolojik olarak sıralanabilmektedir. Tedarik zinciri esnekliği ile birlikte dış çevre faktörleri olabildiğince kontrol altına alınabilir ve yönetilebilir diyebiliriz.

Bu faktörler bazı unsurlara göre seçilmelidir. Gerektiği durumlarda analizlerden faydalanılabilir. Örneğin; "Neden-neden analizi, işletmenin belirlediği gümrükleme, aktarma limanlarından çıkış ve giriş vs. gibi süreçlerin neden tutturulamadığını belirleyen ana neden atama sisteminin sonucunda ortaya çıkan bir rapor olarak karşımıza çıkmaktadır. Bu rapor sonucunda 80/20 analizi gibi analizler yapılarak faktörler belirlenmekte ve bu belirlenen faktörler işletmenin son 6 senelik verilerinden elde edilmektedir. KPI, gümrükleme, aktarma limanlarından çıkış ve giriş vs. gibi faktörler aynı zamanda gümrükleme performansı, tedarikçinin performansını da takip etmeyi sağlayarak onların da göz önünde bulundurulacağı faktörlerin içine sokmayı sağlamaktadır. Bu faktörler işletmelerin kendilerinden çıktı olarak alınır ve uygulamaya konulursa performans attırılabilir ve başarı sağlanabilir. Bu doğrultuda işletme kendi faktörlerini oluşturmak için geçmişe dönük bir araştırma gerçekleştirmiş ve araştırma sonucunda elde edilen veriler gerekli faktörleri belirlemede ve uygulamaya koymada etkili olmuştur. Bu noktada işletmelerin araştırma kısmına önem vermeleri gerekliliği söylenebilmektedir. Bu araştırmalardan elde edilen veriler çeşitli analizler ile işletmelerin ihtiyaçlarını karşılamada etkili olmaktadırlar. Örneğin işletme, bunun için "neden-neden analizi" ile "80/20 analizi" gibi analizler kullanarak program için gerekli faktörleri ortaya çıkartmışlardır.

Yapılan veri analizleri sonucunda, Tedarik Zincirinde Esneklik kavramının görüşmeciler tarafından işletmeların devamlılığı ve gelişmesi için önemli bir yapı taşı olduğu ortaya çıkartılmıştır. Bir görüşmeci tedarik zinciri esnekliğinin önemini "Bir işletmenın devamlıı̆ı esneklik seviyesine bağıı olarak değişmektedir."şeklinde açıklamıştır. Dördüncü Taraf lojistik işletmelarının esneklikle olan ilişkisini ise "Müşteri memnuniyetini korumak ve artırmak, yeni müşteriler için çekici hale gelmek ve farklılaşmak için bir anahtar" olarak belirtmiştir.

Ortaya çıkarılan faktörlerin iç veya dış olarak nasıl ayrılması gerektiği noktada ise; program daha çok dış faktörlere dayanan bir sistemdir. İ̧ faktörlerin göz önünde bulundurulmama sebepleri de LLP olarak tedarik zincirini yönetmekten sorumlu olmak olarak değerlendirilebilmektedir. İç faktörler de göz önünde bulundurulursa iş tanımından ayrı düşülmektedir. Bununla birlikte iç faktörlerden kaynaklanan sorunlarla ilgili işletmelerin uyarıldığı durumlar da olmaktadır. Fazla insana bağlı bir sisteme sahip olan işletmelerde genelde planlama sorunları ortaya çıkmaktadır. Örneğin; Dört sene önce demuraja fazla ödeme yapan işletmenin diğer sıklık durumları için regresyon analizi yapılmış, dokümantasyon ve mevsimsellikten kaynaklanan problemler tespit edilerek işletmelerin dönemsel olarak hazırlanması sağlanmıştır iç uyarı sistemleri olmasına rağmen işletme, LLP iç planlamaya girmeyi tercih etmemektedir. Özel olarak hazırlanan program, işletme tarafından özellikle dış faktörlere dayandırmışlardır. Fakat iç faktörlerden kaynaklanacak herhangi bir problemin de kontrol altında tutulması önem taşımaktadır. Burada en çok dikkat edilmesi gereken nokta ise planlamaların doğru bir şekilde yapılmasıdır. Program için dış faktörler işletme adına iç faktörlerden daha fazla önem taşımakta olduğu saptanılmıştır.

Bir işletmenin tedarik zincirinde esnekliği kullanmasının birçok yararı bulunmaktadır. Müşteri memnuniyetinin artması, bilinmeyen bir sistem kullanımı ile öteki işletmelerden farklılaştıklarını hissetmeleri gibi faktörler vardır. Endüstri 4.0, büyük veri, dijitalleşme gibi günümüzde güncel olan konularla ilgili olarak işletmelerin kendi yeterliliklerini kanıtlamaları için de avantajı olan ve insan faktörünü kaldırarak hatayı da azaltmaya dayalı bir sistem olarak karşımıza çıkmaktadır. Olarak karşımıza çıkmaktadır. Geliştirilen program ile birlikte işletmeler farklılaşmakla birlikte müşteri memnuniyeti de artmaktadır. Bu süreçte özellikle yeni teknolojiler önem taşımaktadır.

Bir işletmenin tedarik zinciri esnekliği kullanması sadece avantaj sağlamak ile kalmaz aynı zamanda da sektörde yer alan tehditlerden kaçınmayı ve fırsatları da yakalamayı sağlamaktadır. Hat duruşları, müşteri memnuniyetsizliğini azaltmak, geç üretim ve onun getirdiği satış kaybı, prestij kaybı, müşteri kaybı ve para kaybından kaçınmaya yönelik olarak belirlenmektedir. Maliyetlerin artması rekabeti de azaltan bir faktör olduğu için işletme bu tehditten de kaçınabilir. Müşteriye direkt etkisi olan program tedarik masraflarını azaltarak farklı tehditlerden kaçınma imkânı da sunmaktadır. Geliştirilen program müşterinin müşterisine dahi etki edebilecek kapasitededir. Bilinmeyen veya takip edilmeyen masrafları azaltarak mali sorunlardan 
kaçınılabilinmektedir. Data eksikliğinden kaynaklanan riskleri de ortadan kaldırması yönü işletmelere daha geniş bir bakış açısıyla bakma fırsatı sunmaktadır Bunun sonucunda da sektördeki tehditler daha iyi analiz edilebilmektedir. Özellikle müşteri memnuniyeti ile maliyetlerin düşürülmesi en önemli çıktılar olarak karşımıza çıkmaktadır. Araştırmalara dayanarak analizlerin yapılması ve dış faktörleri dikkate alarak hareket etme özellikleri yine geliştirilen programın tedarik zinciri yönetiminde farklı durum ve şartlara karşı gelebilme noktasında önem taşıdığı söylenebilmektedir.

İşletmenin geliştirmiş olduğu program ile tedarik zinciri zayıflığı ortadan kalkmakta aynı zamanda bir zayıflık olan tedarik zincirindeki insan yatırımını da ortadan kaldırmaktadır. Bütün bunların sonucu olarak rekabetçi yapı arttığı için işletmenin büyüme fırsatı yakalaması mümkün olabilmektedir. Riskleri ayırarak bu riskleri ortadan kaldırması yönüyle de işletmelerin kendi zayıf yönlerini kapatmaya değil sektörü gözlemlemeye vakit ayırabilmekleri açısından önem taşımaktadır. Tedarik zinciri üzerinde bulunan zayıflıklar geliştirilen program ile birlikte ortadan kalkmaktadır. Bunun neticesinde işletmelerin farklılaşarak öne çıkmaları muhtemeldir.

Risk analizine genelde zaman ayırmayan işletmeler zayıflıklarının da ne olduğunu bilmemekte bu yüzden geliştirilen raporlama sistemi ile zayıflıkların ne olduğunu ortaya konulmaktadır. Geliştirilen program, riskleri elimine edebilecek aksiyonlar alabilmeleri için daha yol gösterici olarak faaliyet gösteren bir sistem olarak karşımıza çıkmaktadır. Günümüzde hala internette bir sorun yaşadığında bütün sistemi çöken, maliyetleri önemsemeyen işletmeler olduğu için geliştirilen program bu işletmelere de daha geniş bir bakış açısı sunabilme yeteneğine sahiptir. Program ile birlikte işletmelerin kendi içlerinde bulunan zayıf noktalar tespit edilebilir ve var olan zayıfıklar en aza indirilebilir. Bunun sonucunda maliyet düşürme, zayıf yönleri güçlendirme gibi avantajlar elde edilebilir. Tedarik zincirinde esneklik ile birlikte sadece zayıf yönlerin belirlenmesiyle yetinilmiyor aynı zamanda işletmelerin güçlü yönleri de ortaya konularak tedarik zinciri de öncekinden daha fazla güçlendirilmektedir. Yine aynı zamanda müşteri memnuniyeti ile ilgili olan problemler çözüme kavuşturulurken bu sistemde müşteri memnuniyeti sürdürülebilir biçimde en üst düzeyde tutulmaktadır.

Pro-aktivite, sorunlarla daha önceden yapılan planlar dâhilinde başa çıkabilmek, masrafları azaltma, dirençlik ve sağlamlık gibi faktörlerin bir tedarik zincirinde bulunması tedarik zincirinde esneklik kavramını ortaya çıkartır. Yine belirtilen sözler kapsamında masrafları en aza indirme ve çevik davranma noktasında yine esneklik tanımı için geçerli unsurlar göze çarpmaktadır. işletmenin esneklik programını kullanmasının temel sebebi olarak envanter maliyetini en az seviyeye çekmek olduğu görülmektedir. Bu en aza indirilmiş envanterin hassas durumlar ile başa çıkabilmenin yolu esneklik ile sağlanmaktadır.

Rekabet durumunu yükseltmek ve diğer işletmelerden öne çıkabilmek adına esneklik kavramının önemli olduğu söylenebilir. İşletmenin geliştirmiş olduğu esneklik programı geribildirimler ile geliştirilen bir sisteme dayanmakla birlikte işletmelerin gereksiz maliyetlerini azalttığı gibi yoğunluk olan bölgeler için önceden uyarı sistemi geliştirilebilecektir. Bu sistemde tedarik zincirini etkileyebilecek dış faktörler göz önünde bulundurulur. Uyarı önceden geldiği için hem dış çevreden kaynaklanan hem de hava şartları gibi faktörlerden kaynaklanan problemler en aza indirilebilir.

Esneklik programı sisteminin işletmelere avantajları Müşteri memnuniyetinin artması, bilinmeyen bir sistem kullanımı ile öteki işletmelerden farklılaştıklarını hissetmeleri gibi faktörlere dayanmaktadır. Endüstri 4.0, büyük veri, dijitalleşme gibi günümüzde güncel olan konularla ilgili olarak işletmelerin kendi yeterliliklerini kanıtlamaları için de avantajlı olan bir sistem olarak karşımıza çıkmaktadır. Esneklik programı daha çok dış faktörlere dayanan bir sistemdir. İç faktörleri göz önünde bulundurmama sebebimiz de tedarik zincirini yönetmekten sorumlu olmaktır. íç faktörler de göz önünde bulundurulursa iş tanımından ayrışılabilir.

Risk analizine genelde zaman ayırmayan işletmeler zayıfıklarının da ne olduğunu bilmemektedirler. Bu yüzden Esneklik programı, raporlama sistemi ile zayıfıkların ne olduğunu ortaya koymaktadır. Hat duruşları, müşteri memnuniyetsizliğini azaltmak, geç üretim ve onun getirdiği satış kaybı, prestij kaybı, müşteri kaybı ve para kaybından kaçınmaya yöneliktir. Maliyetlerin artması rekabeti de azaltan bir faktör olduğu için işletme bu tehditten de kaçınılabilir. Müşteriye direkt etkisi olan Esneklik programı tedarik masraflarını azaltarak farklı tehditlerden kaçınma imkânı da sunmaktadır. Esneklik programı müşterinin müşterisine dahi etki edebilecek kapasite olarak görülmektedir. Riskleri elimine edebilecek aksiyonlar alabilmeleri için daha yol gösterici olarak faaliyet gösteren bir sistemdir. Günümüzde hala internette bir sorun yaşadığında bütün sistemi çöken, maliyetleri önemsemeyen işletmeler olduğu için Esneklik programı bu işletmelere de daha geniş bir bakış açısı sunabilmektedir. Tablo 4'te yapılan çalışma sonucunda ulaşılan tedarik zinciri esnekliği avantajları incelenmiştir. 
Tablo 4: Tedarik Zinciri Esnekliği Avantajları

\begin{tabular}{|c|c|}
\hline \multicolumn{2}{|l|}{ Tedarik Zincirliği Esnekliğinin Sağladığı Avantajlar } \\
\hline Hataları en aza düşürmek, & $\begin{array}{l}\text { Geçmişte yer alan tecrübelerden } \\
\text { yararlanarak öngörüler oluşturmak, }\end{array}$ \\
\hline Maliyetleri en aza düşürmek, & $\begin{array}{l}\text { Müşteri kaybının önüne geçip mevcut } \\
\text { müşteriyi korumak, }\end{array}$ \\
\hline Daha az envanter kullanmak, & Tehditleri daha iyi analiz edebilmek, \\
\hline Kırılgan yapıyı sağlamlaştırmak, & $\begin{array}{l}\text { Tedarik zinciri zayıflığını ortadan } \\
\text { kaldırmak ve rakiplerden ayrışarak sektör } \\
\text { içinde sürat kazanmak, }\end{array}$ \\
\hline $\begin{array}{l}\text { Sorunlu bölgeler gibi noktalarda öngörü oluşturmak ve } \\
\text { buralara özgü uyarı sistemini geliştirmek, }\end{array}$ & Rekabet üstünlüğünü elde etmek, \\
\hline Dış faktörleri göz önünde bulundurmak, & $\begin{array}{l}\text { Öz niteliklere odaklanmada üstünlük } \\
\text { sağlamak ve iş tanımını kuvvetlendirmek, }\end{array}$ \\
\hline İşletmeye özel analizler hazırlamak, & $\begin{array}{l}\text { İşletmenin dışarıdan da kontrol } \\
\text { edilmesini sağlamak, }\end{array}$ \\
\hline $\begin{array}{l}\text { İç faktörlerin sürekli kontrol altında tutulmasıyla } \\
\text { esnekliği daha yalın bırakmak, }\end{array}$ & $\begin{array}{l}\text { Tehlike ve risk karşısında hızlı reaksiyon } \\
\text { gösterebilmek ve daha hızlı, daha basit } \\
\text { daha az maliyetli çözümler üretmek, }\end{array}$ \\
\hline $\begin{array}{l}\text { Müşteri sayısının ve müşteri memnuniyetinin } \\
\text { arttırılması, }\end{array}$ & $\begin{array}{l}\text { İşletmenin zayıf yönlerini güçlendirirken } \\
\text { güçlü yönlerini de ön plana çıkarmak, }\end{array}$ \\
\hline Dijitalleşen dünyaya uyum sağlamak, & $\begin{array}{l}\text { Teknolojiyi sürdürülebilir olarak } \\
\text { kullanmak ve teknolojiden azami faydayı } \\
\text { sağlamak, }\end{array}$ \\
\hline
\end{tabular}

\section{SONUÇ VE ÖNERILER}

Çağımızda her alanda görülen değişim lojistik alanında da etkili olmuştur. Lojistiğin değişim göstermesi ile birlikte 4'üncü Taraf Lojistik kavramı ortaya çıkmış ve buna bağlı olarak müşteriyle birlikte müşteri istek ve ihtiyaçlarının daha fazla ön planda olduğu teknoloji ile bütünleşmiş bir anlayış ortaya çıkmıştır. Pro-aktive, sorunlarla daha önceden yapılan planlar dâhilinde başa çıkabilmek, masrafları azaltma, dirençlik ve sağlamlık gibi faktörler ise tedarik zincirinde esneklik kavramını ortaya çıkartmış bu doğrultuda yapılan çalışmalar tedarik zincirinde esnekliğin ne derece önemli bir süreç olduğunu ortaya koymuştur. Tedarik zincirinde esneklik uygulamaya konulduğunda hem işletme açısından hem de müşteri açısından öngörülemeyen problemlerin en aza indirgenmesi düşünülmüş ve bu süreç 4'üncü Taraf Lojistik ile birleştirildiğinde işletmeye özel bir kavram ortaya çıkmıştır.

Doğada ya da bilimde her ihtiyacın bir problemden kaynaklandığı gibi Esneklik kavramı da bir problemden ortaya çıkmış ve sistem başarılı bir şekilde uygulamaya konulmuştur. Tedarik zincirinde esnekliğin en önemli özelliği olarak geribildirimlerden yararlanıyor olması göze çarpmaktadır. Geribildirimler sonucu oluşturulan sistem dış çevre faktörlerinin göz önünde bulundurulması ile dikkat çekici bir diğer özellik olarak ortaya konulabilir. Sürekli olarak gelişen ve değişen dünyada gerçekleşen insani, politik, ekonomik, sosyal, teknolojik ve çevresel gibi faktörler esnekliğin geliştirilmesinin önemli etkenleridir. Dış faktörlerin analizlerinin yapılması ve rapor haline getirilmesi yine sistemin düzenli ve disiplinli bir yapıya sahip olduğunu göstermektedir. Bu sistemde işletmenin kendini ispatlaması ve rakiplerinden ayrılması, bir adım öne çıkıyor olması durumu söz konusudur. Çünkü dış dünya tehditlerinin en aza indiriliyor olması hem müşteri memnuniyetini sağlayacak hem mevcut müşteriyi koruyacak hem de işletmeye yeni müşteri kazandırarak işletmeyi karlı ve kazançlı hale getirecektir. Daha önceden öngörülebilen problemlerin erken çözümü hem zaman kazandıracak hem de maliyetleri düşürecektir aynı zamanda işletmenin de içerisinde bulunduğu pazarı gözlemlemesi için zaman kazandıracaktır.

İşletme içinde yer alan zayıflıkların da ortaya konulup bu zayıflıkların güçlü hale getirilmesi, güçlü yönlerin daha çok ön plana çıkarılması tedarik zincirinde esneklik ile sağlanabilmektedir. Bu doğrultuda işletme içerisinde bulunan faktörlerinde sürekli olarak kontrol altında tutulması söz konusudur. Bu kontrol işletme lehine kararlar almak için fayda sağlamaktadır. Ayrıca hem iç faktörlerden hem de dış faktörlerden kaynaklanan kırılgan yapıyı sağlamlaştırıp, kırılganlığı ortadan kaldırmak kolaylaşacaktır.

Tedarik zincirinde esnekliğin en önemli özelliklerinden biri olarak geçmiş deneyimleri kullanması ve geçmişten yararlanmasından bahsetmek gerekmektedir. Daha önceden yaşanan tecrübeler işletmenin gerek risk yönetimi gerek ise esnekliğinin sağlanıp 
yeteneklerinin arttırılması noktasında önem taşımaktadır. Geleceğin öngörülemeyen risk ve tehditlerine önlem alabilmek için geçmişte yaşananların incelenmesi gerekmektedir.

Sonuç olarak, literatür taraması ve incelenen işletmenin kendi ihtiyaçları doğrultusunda geliştirdiği programının incelenmesi neticesinde elde edilen bulgular kapsamında erken uyarı programlarının sektöre aşağıda sıralanan özellikleri katma değer olarak sağlayabileceği değerlendirilmektedir. Tablo 2'de belirtilen özellikler aynı zamanda belirlenen araştırma sorusunun cevabını oluşturmaktadır.

\section{KAYNAKÇA}

Acar, Z., Gürol, P. (2013). Türkiye'de lojistik yazınının tarihsel gelişimi. İşletme Araştırmaları Dergisi, 5(3): $289-312$.

Acar, Z., Köseoğlu, M. (2014). Lojistik yaklaşımıyla tedarik zinciri yönetimi. Nobel Yayıncılık, 1.Basım, Ankara.

Aydın, N., Köseoğlu, M. (2016). Information technology competency in selection of 3pl service provider for businesses. Global Business Research Congress (GBRC), May 26-27, 2016, Istanbul ISSN: 2459-0762. (ss:485-500).

Bayraktutan, Y., Özbilgin, M. (2015). Lojistik maliyetler ve lojistik performans ölçütleri. Maliye Araştırmaları Dergisi, Yıl:1, Cilt:1, Sayı:2:95-112.

Çancı, M., Erdal, M. (2003). Lojistik yönetimi. Erler Matbaacılık San. Ve Tic. A.Ş., 1.Baskı, İstanbul.

Christopher, M. (2011). Logistics and supply chain management: creating value-adding networks. Pearson Education Limited, 4th ed., Edinburgh Gate Harlow.

Eker, Ö. (2006). Lojistik yönetimi ve tedarik lojistiği sürecinde performansın arttırılması. İstanbul Teknik Üniversitesi Fen Bilimleri Enstitüsü, Yüksek Lisans Tezi (Yayınlanmış).

Fourth Party Logistics (4'üncü Taraf Lojistik). http://www.dhl.co.uk/en/logistics/supply chain solutions/fourth_party logistics 4'üncü Taraf Lojistik.html (Erişim Tarihi: 20. 04. 2018).

Gravier, M., Farris, M. (2008). An analysis of logistics pedagogical literature: past and future trends in curriculum, content, and pedagogy. The International Journal of Logistics Management, S: 19(2): 234-235.

Güleç, İ. F., Karagöz, B. (2008). E-lojistik ve Türkiye'de e-lojistik uygulamaları. Kocaeli Üniversitesi, Sosyal Bilimler Enstitüsü, Dergisi 15(1):73-91.

Hai, L., Yirong, S. (2002). An approach towards overall supply chain efficiency - a future oriented solution and analysis in inbound process. School of Economics and Commercial Law Göteborg University, Logistics and Transport Management Masters Thesis No. 2002:29.

Hugos, M. (2003). Essentials of supply chain management. John Wiley\&Sons Inc., Hoboken, New Jersey.

OECD. (2014). Guidelines for resilience systems analysis. OECD Publishing.

Özdemirel, B. (2004). Lojistik hizmetlerin dışarıdan sağlanması ve 4'üncü taraf lojistik kavramı. İstanbul Teknik Üniversitesi, Fen Bilimleri Enstitüsü İşletme Mühendisliği, Yüksek Lisans Tezi (Yayınlanmış).

Özdener, H. H. (2010). Lojistikte toplam kalite yönetimi. Kadir Has Üniversitesi Sosyal Bilimler Enstitüsü, Yüksek Lisans Tezi (Yayınlanmış), İstanbul.

Özovacı, E. (2016). The new logistics methods. Proceedings of INTCESS2016 3rd International Conference on Education and Social Sciences, 8-10 February 2016- Istanbul, Turkey, 409-412.

Öztürk, D. (2016). Tedarik zinciri yönetimi süreçlerini etkileyen faktörler. Uluslararası Sosyal ve Ekonomik Bilimler Dergisi, 6 (1): 17-24.

Pettit, T. J., Croxton, K. L., Fiksel, J. (2013). Ensuring supply chain resilience: development and implementation of an assessment tool. Journal of Business Logistics, 2013, 34(1):46-76.

Remigio, H. C. (2012). Modelling resilience in supply chain. Universidade Nova de Lisboa, Fen ve Teknoloji Fakültesi Endüstri Mühendisliği Doktora Tezi (Yayınlanmış).

Şahin, A. G., Berberoğlu, N. (2011). Lojistik outsourcing karar süreci ve 3PL seçim kriterleri. AJIT-e: Online Academic Journal of Information Technology Vol:2 Num:5.

Tang, C. S. (2006a). Perspectives in supply chain risk management. International Journal of Production Economics, 103(2): $451-488$.

Vatansever, K. (2004). Üçüncü taraf lojistik işletmelerinin hizmet kalitesinin ölçümü üzerine bir araştırma. Dumlupınar Üniversitesi, Sosyal Bilimler Enstitüsü İşletme Ana Bilim Dalı Yüksek Lisans Tezi, Kütahya.

Waters, D. (2003). Global logistics and distribution planning strategies for management. Kogan Page Limited,4th Edition, London, United Kingdom. 
Weele, A. J. V. (2014). Satın alma ve tedarik zinciri yönetimi, Purchasing and supply chain management. Ekim 2014 - İstanbul - Literatür Kitabevi Basın Sanayi ve Ticaret Ltd. Şti. Çeviri editörü: Metin Çancı, Çevirmen: Timuçin Binder .

What is Logistics and Supply Chain Management, https://www.supplychainopz.com/2012/04/what-is-logistics-and-supply-chainmanagement.html (Erişim Tarihi: 20. 04. 2018).

Kolb, B., Cioe, J. (2018). Absence of recovery or dendritic reorganization after neonatal posterior parietal lesions. Psychobiology, $26,134-142$. DOI: 745322/KMML.2018.45326 